\title{
PENGARUH SELF CONFIDENCE SISWA SMP TERHADAP KEMAMPUAN BERPIKIR KRITIS MATEMATIS
}

\author{
Mira Siti Hajar ${ }^{1}$, Eva Dwi Minarti ${ }^{2}$ \\ IKIP Siliwangi, Jl. Terusan Jend Sudirman, Cimahi \\ ${ }^{1}$ mirasitihajar@gmail.com
}

\begin{abstract}
Abstrak
Penelitian ini bertujuan melihat adakah pengaruh positif self confidence siswa SMP terhadap kemampuan berpikir kritis matematis. Subjek penelitian yang diambil 30 siswa kelas IX di salah satu SMP swasta di Kota Cimahi. Metode yang digunakan pada penelitian ini yaitu metode korelasional dengan pendekatan kuantitatif. Instrumen dalam penelitian ini meggunakan tes kemampuan berpikir kritis matematis dan angket self confidence. Tes kemampuan berpikir kritis matematis terdiri dari 4 butir soal yang diadopsi dari Yulia (2015) dan angket self confidence terdiri dari 41 skala pernyataan yang diadopsi dari Sumarmo (2015) dengan indikator : a) percaya kepada kemampuan sendiri, tidak cemas, merasa bebas, dan bertanggung jawab atas perbuatannya. b) bertindak mandiri dalam mengambil keputusan. c) Memilih konsep diri yang positif, hangat dan sopan, dapat menerima dan menghargai orang lain. d) memiliki konsep diri yang positif, hangat dan sopan dapat menerima dan menghargai orang lain. e) berani mengungkapkan pendapat dan memiliki dorongan untuk berprestasi. f) saya mengenal kelebihan dan kekurangan diri sendiri. Hasil dari penelitian ini menunjukkan self confidence siswa tidak memiliki pengaruh terhadap kemampuan berpikir kritis matematis. Berdasarkan analisis lanjut penyebab self confidence yang kurang pada siswa dalam penelitian ini yaitu tidak ada motivasi siswa ketika menyelesaikan soal matematika. Jika siswa tidak memiliki motivasi dalam menyelesaikan soal matematika maka siswa itu tidak akan berani mengungkapkan pendapat dan memiliki dorongan untuk berprestasi (indikator self confidence). Yang dapat mempengaruhi siswa terhadap kemampuan berpikir kritis yaitu kemauan dalam belajar dan menyelesaikan soal matematika, motivasi belajar dan self efficacy merupakan faktorfaktor lain yang dapat mempengaruhi kemampuan berpikir kritis siswa.
\end{abstract}

Kata Kunci: Kemampuan Berpikir Kritis Matematis siswa SMP, Self Confidence siswa SMP, Pengaruh.

\begin{abstract}
This research aims to look at are the positive influence of JUNIOR HIGH SCHOOL students ' self confidence against the ability of critical thinking mathematically. The subject of the research taken 30 students of class IX on one of the private JUNIOR HIGH SCHOOL in the city of Greenacres. The methods used in this study i.e., a quantitative approach with korelasional method. Instrument in this study with critical thinking ability test mathematically and the now self confidence. Mathematical ability test critical thinking consists of 4 rounds reserved adopted from Yulia (2015) and the now self confidence consists of 41 scale statements adopted from Sumarmo Airport (2015) with indicator: a) believe in the capability of its own, not anxious, feel free, and responsible for his actions. b) acted independently in taking decisions. c) Choose a positive self concept, warm and polite, can accept and appreciate others. d) have a positive self concept, warm and polite can accept and appreciate others. e) dared to express an opinion and have the urge to Excel. f) I know the advantages and disadvantages of oneself. The results of this study indicate students ' self confidence has no influence on the ability of critical thinking mathematically. Based on further analysis of the causes of the less self confidence in students in this study i.e. no motivation of students when completing a math problem. If students do not have the motivation to complete a math problem so that students would not dare express an opinion
\end{abstract}


and have the urge to Excel (an indicator of self confidence). That can influence students towards critical thinking ability, namely a willingness in learning and completing a math problem, learning motivation and self efficacy was the other factors that can affect the ability of critical thinking students.

Keywords: Critical thinking ability of JUNIOR HIGH SCHOOL students Mathematically, JUNIOR HIGH SCHOOL students, Self Confidence, influence.

\section{Pendahuluan}

Kemampuan berpikir kritis adalah bagian yang penting dalam suatu kemampuan matematis yang sangat perlu untuk dikembangkan. Berpikir kritis dapat menjadikan siswa tanggap terhadap permasalahan yang ada, dengan demikian siswa dapat menyaring informasi yang telah diterima. Siswa diberikan kesempatan untuk mengaplikasikan keterampilannya dalam berpikir sehingga pendugaan-pendugaan didasarkan pada pengalaman atau pengetahuan siswa, sehingga mudah dalam memahami konsep.

Kemampuan berpikir tingkat tinggi salah satunya yaitu kemampuan berpikir kritis. Mengajarkan kemampuan berpikir kritis kepada siswa diharapkan siswa mampu mengembangkan pola berpikir dengan baik agar generasi muda di masa yang akan datang dapat bersaing di tingkat global (Chandra Novtiar \& Usman Aripin, 2017). Menanamkan kebiasaan kemampuan berpikir kritis pada siswa perlu untuk diterapkan sehingga siswa dapat menelaah berbagai persoalan yang dihadapi dalam kehidupan sehari-hari. Agar dapat mencapai kemapuan berpikir kritis matematis dalam pembelajaran matematika siswa memerlukan sikap Self Confidence (kepercayaan diri).

Sikap Self Confidence sangatlah dibutuhkan oleh siswa agar mampu memaksimalkan kemampuan yang dimilikinya. Self Confidence adalah suatu kepercayaan tehadap dirinya sendiri atas kemampuan yang dimiliki yang terjadi dalam kehidupannya. Self Confidence atau kepercayaan diri dapat memperkuat motivasi dalam mencapai keberhasilan, karena semakin tinggi kepercayaan terhadap diri sendiri, semakin kuat juga tekad untuk menyelesaikan segala tugasnya ( Hendriana, 2012 ).

Menurut Yates (Hendriana,dkk,2017) self confidence sangat penting dimiliki oleh siswa agar berhasil saat belajar matematika. Menurut Ennis (Hendriana\&Sumarmo,2014) berpikir kritis matematik merupakan berpikir refleks yang memiliki alasan serta difokuskan dengan penetapan pada apa yang diyakini atau yang dikerjakan. Maka dari itu siswa perlu memliki kemampuan berpikir kritis matematik yang baik. Sikap self confidence pada siswa dapat menunjang keberhasilan siswa ketika menyelesaikan permasalahan matematika dengan kemampuan berpikir kritis matematis siswa SMP. Berdasarkan penelitian dari Komara ( 2016 ) 
prestasi belajar merupakan sebuah hasil dari proses belajar yang baik, dilihat dari kemampuan penguasaan materi dalam pembelajaran matematika dan merupakan hasil penilaian secara menyeluruh. Menurut penelitian Purwasih (2015) Self confidence siswa SMP dapat berperan aktif dalam mengkonstruksi pengetahuan barunya dengan menggali kemampuan yang ada, mengajukan dugaan/hipotesis, mencoba menemukan sendiri dengan kemampuan prasyarat yang mereka miliki. Dengan ini peneliti akan melakukan penelitian dengan judul "Pengaruh Self Confidence Siswa SMP Terhadap Kemampuan Berpikir Kritis Matematis”. Karena siswa SMP diharapkan mempunyai kemampuan kritis dengan self confidence yang baik.

\section{Metode Penelitian}

Metode yang digunakan dalam penelitian ini yaitu metode korelasional. Populasi yang diambil dalam penelitian ini yaitu siswa SMP di salah satu sekolah di Kota Cimahi. Subjek yang terlibat dalam penelitian ini yaitu 30 siswa kelas IX SMP swasta di salah satu sekolah di Kota Cimahi. Instrumen yang digunakan pada penelitian ini yaitu tes kemampuan berpikir kritis matematis dan angket self confidence. Tes kemampuan berpikir kritis matematis terdiri dari 4 butir soal yang diadopsi dari Yulia (2015) dan angket self confidence terdiri dari 41 skala pernyataan yang diadopsi dari Sumarmo (2015) dengan indikator : a) percaya kepada kemampuan sendiri, tidak cemas, merasa bebas, dan bertanggung jawab atas perbuatannya. b) bertindak mandiri dalam mengambil keputusan. c) memilih konsep diri yang positif, hangat dan sopan, dapat menerima dan menghargai orang lain. d) memiliki konsep diri yang positif, hangat dan sopan dapat menerima dan menghargai orang lain. e) berani mengungkapkan pendapat dan memiliki dorongan untuk berprestasi. f) saya mengenal kelebihan dan kekurangan diri sendiri. Indikator pada kemampuan berpikir kritis matematis siswa yang digunakan:

1. Memeriksa kebenaran argumen pernyataan dan proses solusi.

2. Menyusun pertanyaan disertai alasan.

3. Mengidentifikasi data yang relevan dan tidak relevan suatu masalah matematika.

4. Mengidentifikasi asumsi.

5. Menyusun jawaban atau menyelesaikan masalah matematika dengan disertai alasan.

Indikator kemampuan berpikir kritis matematis siswa yang digunakan menurut Sumarmo (2016).

\section{Hasil dan Pembahasan}

Berdasarkan hasil dari analisis data terlebih dahulu dilakukan uji normalitas dan uji linearitas dan uji linearitas data yang disajikan pada Tabel 1 sebagai berikut.

Tabel 1. Uji Normalitas pada Self Confidence dan Kemampuan Berpikir Kritis Matematis 


\begin{tabular}{lllllll}
\hline & \multicolumn{3}{l}{ Kolmogorov-Smirnov $^{\mathrm{a}}$} & \multicolumn{3}{l}{ Shapiro-Wilk } \\
& Statistic & Df & Sig. & Statistic & df & Sig. \\
\hline berpikir_kritis & .190 & 30 & .007 & .911 & 30 & .015 \\
self_confidence & .097 & 30 & $.200^{*}$ & .973 & 30 & .624 \\
\hline
\end{tabular}

Berdasarkan Tabel 1 dengan hasil uji normalitas di lihat dari nilai signifikansi ke dua varibel > 0,05 maka Ho di terima artinya sampel yang digunakan berdistribusi normal. Selanjutnya dilakukan uji linearitas self confidence dengan kemampuan berpikir kritis matematis. Uji linearitas digunakan untuk mengetahui linearitas hubungan antara masing-masing variabel penelitian.

Tabel 2. Uji Linearitas pada Self Confidence dan Kemampuan Berpikir Kritis Matematis.

\begin{tabular}{|c|c|c|c|c|c|c|c|}
\hline & & & $\begin{array}{l}\text { Sum o } \\
\text { Squares }\end{array}$ & Df & Mean Square & $\mathrm{F}$ & Sig. \\
\hline \multirow{5}{*}{$\begin{array}{l}\text { berpikir_kritis } \\
\text { self_confidence }\end{array}$} & \multirow{3}{*}{$\begin{array}{l}* \text { Between } \\
\text { Groups }\end{array}$} & (Combined) & 8118.500 & 24 & 338.271 & 2.217 & .192 \\
\hline & & Linearity & 253.103 & 1 & 253.103 & 1.659 & .254 \\
\hline & & $\begin{array}{l}\text { Deviation from } \\
\text { Linearity }\end{array}$ & 7865.397 & 23 & 341.974 & 2.241 & .188 \\
\hline & \multicolumn{2}{|c|}{ Within Groups } & 763.000 & 5 & 152.600 & & \\
\hline & \multicolumn{2}{|l|}{ Total } & 8881.500 & 29 & & & \\
\hline
\end{tabular}

Berdasarkan Tabel 2 hasil uji linearitas di atas dari self confidence dan kemampuan berpikir kritis matematis diperoleh nilai $\mathrm{f}=2,241$ dan nilai Sig. Deviation from Linearity $=0,188$ maka nilai Sig. Deviation from Linearity > 0,05. Dapat dilihat dari hasil Sig. Deviation from Linearity $=0,188$ yang lebih dari nilai Sig. maka terdapat hubungan linear yang kuat.

Tabel 3. Uji Regresi pengaruh self confidence terhadap Kemampuan Berpikir Kritis Matematis.

\begin{tabular}{lllllll}
\hline Model & & Sum of Squares & Df & Mean Square & F & Sig. \\
\hline 1 & Regression & 253.103 & 1 & 253.103 & .821 & $.373^{\mathrm{a}}$ \\
& Residual & 8628.397 & 28 & 308.157 & & \\
& Total & 8881.500 & 29 & & & \\
\hline
\end{tabular}

Berdasarkan uji regresi pada Tabel 3, hasil nilai Sig. sebesar 0,373 maka nilai Sig 0,373 $>$ kriteria signifikansi $(0,05)$ yang menunjukkan bahwa self confidence siswa SMP secara signifikansi tidak terdapat pengaruh terhadap kemampuan berpikir kritis matematis siswa SMP. Jadi, berdasarkan data di atas bisa ditarik kesimpulan jika self confidence siswa pada kelas yang diteliti, tidak terdapat pengaruh terhadap kemampuan berpikir kritis matematis siswanya. Berdasarkan hasil dari analisis jawaban siswa pada angket dan soal tes soal Kemampuan Berpikir Kritis Matematis. Berdasarkan analisis lanjut dengan memeriksa angker siswa hasilnya siswa yang memiliki self confidence rendah menjawab soal matematika dengan kurang tepat menjadi penyebab self confidence yang kurang pada siswa yaitu di penelitian ini tidak ada motivasi siswa ketika mengerjakan soal matematika. Jika siswa tidak memiliki motivasi dalam menyelesaikan soal matematika maka siswa itu tidak akan berani mengungkapkan pendapat dan memiliki dorongan untuk berprestasi (indikator self confidence). Yang dapat mempengaruhi siswa 
terhadap kemampuan berpikir kritis yaitu kemauan dalam belajar dan menyelesaikan soal matematika, motivasi belajar dan self efficacy merupakan faktor-faktor lain yang dapat mempengaruhi kemampuan berpikir kritis siswa. Karena kurangnya self confidence pada siswa maka motivasi dalam mencapai keberhasilan nya akan kurang. Menurut (Yunita, Rosyana,\& Hendriana, 2018 ) siswa yang memiliki motivasi belajar tinggi ketika menyelesaikan soal kemampuan berpikir kritis matematis maka siswa tersebut dapat menyelesaikan soal tersebut dengan baik, sedangkan siswa yang memiliki motivasi belajar kurang ketika pembelajaran matematika cenderung menyelesaikan soal matematika sesuai pemahaman yang dimilikinya. Berdasarkan penelitian Hari, Zanthy, \& Hendriana (2018) menunjukkan bahwa kemampuan berpikir kritis matematik siswa SMP dipengaruhi positif oleh self efficacy.

Self confidence dapat tumbuh pada diri setiap orang. Self confidence dapat mendorong seseorang dalam mewujudkan harapan serta cita-cita, karena jika individu tidak mempunyai self confidence maka dia akan ragu-ragu dalam mengambil keputusan yang akan merugikan individu serta orang lain. Motivasi belajar yang dimiliki siswa akan mendorong keberanian dalam menyelesaikan soal matematika. Menurut Hendriana (2012) kepercayaan diri akan memperkuat motivasi mencapai keberhasilan, karena semakin tinggi kepercayaan terhadap kemampuan diri sendiri, semakin kuat pula semangat untuk menyelesaikan pekerjaannya .

\section{Simpulan dan Saran}

Dari hasil serta pembahasan dari penelitian ini yaitu diperoleh jika self confidence siswa tidak memiliki pengaruh terhadap kemampuan berpikir kritis matematis. Berdasarkan hasil dari analisis jawaban siswa pada angket dan soal tes soal kemampuan berpikir kritis matematis. Berdasarkan analisis lanjut dengan memeriksa angker siswa hasilnya siswa yang memiliki self confidence rendah menjawab soal matematika dengan kurang tepat menjadi penyebab self confidence yang kurang pada siswa yaitu di penelitian ini tidak ada motivasi siswa ketika mengerjakan soal matematika. Jika siswa tidak memiliki motivasi dalam menyelesaikan soal matematika maka siswa itu tidak akan berani mengungkapkan pendapat dan memiliki dorongan untuk berprestasi (indikator self confidence). Yang dapat mempengaruhi siswa terhadap kemampuan berpikir kritis yaitu kemauan dalam belajar dan menyelesaikan soal matematika, motivasi belajar dan self efficacy merupakan faktor-faktor lain yang dapat mempengaruhi kemampuan berpikir kritis siswa. Karena kurangnya self confidence pada siswa maka motivasi dalam mencapai keberhasilan nya akan kurang. Peneliti berharap siswa rajin dalam belajar dan menyelesaikan soal matematika, mempunyai motivasi belajar, dan bisa memiliki self confidence yang baik dalam menyelesaikan permasalahan matematika. 


\section{Referensi}

Amalia, Y., Duskri, M., \& Ahmad, A. 2015. Penerapan Model Eliciting Activities untuk Meningkatkan Kemampuan Berpikir Kreatif Matematis dan Self Confidence Siswa SMA. Jurnal Didaktik Matematika, 2(2).

Hari, L. V., Zanthy, L. S., \& Hendriana, H. 2018. Pengaruh Self Efficacy Terhadap Kemampuan Berpikir Kritis Matematik Siswa Smp. JPMI (Jurnal Pembelajaran Matematika Inovatif), 1(3), 435-444.

Hendriana,H.2012.Pembelajaran Matematika Humanis dengan Metaphorical Thinking untuk Meningkatkan Kepercayaan DiriSsiswa. Infinity Journal, 1(1), 90103.

Hendriana.H,dkk.2017. Hard Skills dan Soft Skills Matematik Siswa. Bandung: PT Refika Aditama.

Komara, I. B. 2016. Hubungan antara Kepercayaan Diri dengan Prestasi Belajar dan Perencanaan Karir Siswa SMP. PSIKOPEDAGOGIA Jurnal Bimbingan dan Konseling, 5(1), 33-42.

Novtiar, C., \& Aripin, U.2017. Meningkatkan Kemampuan Berpikir Kritis Matematis dan Kepercayaan Diri Siswa SMP melalui Pendekatan Open Ended. PRISMA, 6(2).

Purwasih, R. 2015. Peningkatan Kemampuan Pemahaman Matematis dan Self Confidence Siswa MTS di Kota Cimahi Melalui Model Pembelajaran Inkuiri Terbimbing. Didaktik, 9(1), 16-25.

Sumarmo, U. 2016. Pedoman Pemberian Skor pada Beragam Tes Kemampuan Matematik. Kelengkapan Bahan Ajar Mata Kuliah Evaluasi PembelajaranMatematika pada Program Magister Pendidikan Matematika STKIP Siliwangi: Tidak diterbitkan.

Sumarmo, U. 2015. Pengembangan Dan Contoh Butir Skala Nilai, Karakter, Budaya Dan Aspek Afektif Lain Dalam Pembelajaran Matematika. Makalah dimuat dalam utarisumarmo@dosen. stkipsiliwangi.ac, id.

Yunita, N., Rosyana, T., \& Hendriana, H. 2018. Analisis Kemampuan Berpikir Kritis Matematis berdasarkan Motivasi Belajar Matematis Siswa SMP. JPMI (Jurnal Pembelajaran Matematika Inovatif), 1(3), 325-332. 